\title{
The formation of the willing citizen: Tracing reactive nihilism in late capitalist adult education
}

Maria Olson, Magnus Dahlstedt, Andreas Fejes and Fredrik Sandberg

The self-archived postprint version of this journal article is available at Linköping University Institutional Repository (DiVA):

http:/ / urn.kb.se/ resolve?urn=urn:nbn:se:liu:diva- 143269

N.B.: When citing this work, cite the original publication.

This is an electronic version of an article published in:

Olson, M., Dahlstedt, M., Fejes, A., Sandberg, F., (2017), The formation of the willing citizen: Tracing reactive nihilism in late capitalist adult education, Educational Philosophy and Theory.

https:/ / doi.org/ 10.1080/00131857.2017.1338933

Original publication available at:

https:/ / doi.org/ 10.1080/00131857.2017.1338933

Copyright: Taylor \& Francis (Routledge) (SSH Titles)

http:/ / www.routledge.com/ 


\section{The Formation Of The Willing Citizen - Tracing Reactive Nihilism In Late Capitalist Adult Education}

\section{Maria Olson, Magnus Dahlstedt, Andreas Fejes \& Fredrik Sandberg}

Full reference: Olson, M., Dahlstedt, M., Fejes, A., Sandberg, F. (2017) The formation of the willing citizen: Tracing reactive nihilism in late capitalist adult education. Educational Philosophy and Theory. DOI: 10.1080/00131857.2017.1338933

The role of education in citizen training has been well mapped out in youth education. What has been less studied is how this role comes into being in adult education. By providing illustrative empirical examples from a recently completed study of adult students enrolled in adult education, this article aims to offer a theoretical response to the question of the role of adult education in adult student citizen subjectivity formation. Taking on Diken's concept of 'reactive nihilism', we wish to make the following arguments. First, that citizen formation in adult education, when students are asked about it, is actualised as processes of re(dis)covery of will in order to be(come) a successful and happy citizen in society. Secondly, that these processes point toward a role of adult education as one where these formation processes work in tandem with those of the reactive nihilists. This means that the citizen formation processes made possible in this educational site are those marked out by the desire to mobilise one's will formation so that it adapts to the prevailing societal situation - that of late capitalism, which is a situation not considered by the adult students as possible to change.

Keywords: adult education, citizenship, reactive nihilism, capitalism, desire

\section{Introduction}

The role of education in students' citizen training has been quite well mapped out in research on youth education (cf. Biesta, 2011; Hedtke \& Zimenkova, 2012). What has been less studied, however, is how such training comes into being in adult education. This article aims to make a case for the relationship between the assigned role of adult education, to consider how the process of citizen formation of its students, and the citizen formation processes that actually take place in this educational site work. By offering a theoretically elaborated response to the assigned task of adult education to see to student citizen training, we wish to contribute insights into the particular challenges involved in adult education as an institutional space for citizen training in the present. 
Theoretically underpinned contributions to the field of adult education as a space for citizen training are of importance for at least two reasons. Firstly, because citizenship in relation to the field of education is commonly positioned as a preparation for life. In education policy as well as in teaching practice, adult education is of particular interest to investigate in relation to citizenship. This is so, as adult students - in contrast to students enrolled in youth education - often already are citizens in juridical and legal measures, and are shaped as citizens through their knowledge, dispositions, action-taking and experiences made possible by the discursive, social and material resources at hand (Lawy, Biesta \& Kelly, 2009; Isin \& Nielsen, 2008; Nicoll et al., 2013; Olson et al., 2015). Secondly, theoretical responses to this field are important in order to strengthen and widen the repertoire of perspectives on adult education, partly by giving voice to adult students' own citizen formation processes, and partly by offering theoretically underpinned responses to these voices as a way of theorising the relationship between citizenship and the role of adult education in society.

In the article, attention is directed, more specifically, towards processes of citizen formation, whereby adult students form themselves as citizens when asked to think and talk about themselves as citizens. By providing illustrative empirical examples from a study of young adult students enrolled in Swedish adult education, ${ }^{1}$ and by drawing on a reading of Diken (2009), with a particular focus on his concept of reactive nihilism, we wish to deploy an informed tracing process of citizen formation among adult students. Far from being exhaustive or consolidating, this theorising, a tentative and preliminary tracing, emanates in the following points: that the citizenship formation among adult students stands out as a matter of a mobilisation of will and that this citizen formation - which is immensely self-directed - points to the role of adult education in the present society.

The outline of the article is as follows. Firstly, the concept of citizenship and related research in the field is presented. Thereafter, our theoretical outlining follows. Thirdly, the theoretically underpinned tracing is deployed through illustrative examples of adult students' descriptions of citizenship. Finally, this theoretically informed tracing is discussed in the light of the role of adult education today. 


\section{Citizenship and previous research}

Several adult education researchers highlight the role and function of adult education as a space for citizen formation (cf. Fejes, 2010; Filander, 2012; Milana, 2012; Siivonen \& Brunila, 2014; Rahm \& Fejes, 2015; Sandberg et al, 2016). Much of this research has mainly focused on policy-making (Milana, 2012; Filander, 2012; Nicoll \& Fejes, 2011), and discourses that emerge there (Fejes, 2006). Although there are some empirical studies focusing on citizenship and adult education (Niklasson, 2007) there is a lack of focus on students' own acts of citizen formation as played out in relation to adult education. Even though theorising as well as empirical work on students' own citizen formation has been developed within the project which this article is part of (Rahm \& Fejes, 2015; Sandberg et.al., 2016; Nicoll et.al, 2013; Olson et.al., 2015) there is still a need for intensified research on this assignment of adult education, in particular of research approaching citizenship as something that not only marks out an identity or bestowed status, i.e. something that you are or have, but also something that you do - an activity and action-taking (Isin \& Nielsen, 2008). We particularly address the latter aspect of citizenship, i.e. citizenship as something you do, a process of formation.

The issue of citizen formation in adult education is intimately entwined with citizenship, which is a disputed term in the social sciences. According to a historically established definition, citizenship can be seen as a contract or a status between an individual and the state, which guarantees the member of the community a number of rights—civil, political, and social—but also imposes obligations (Marshall, 1950). This contract is the result of negotiations between the state and the individual or between different groups of individuals (Norman \& Kymlicka, 2005; Isin \& Wood, 1999). The contract has specific meanings regarding the role of citizen training in education (see for example Dahlstedt, Rundqvist \& Vesterberg, 2013; McDonough \& Feinberg, 2005; Olson, 2009, 2012; Öhrn, Lundahl \& Beach, 2011).

However, a number of researchers have emphasised (the need for) dimensions of the term 'citizenship' other than those that are put forth by the judicial dimensions and where the relation between state and individual is in the foreground. One can here point to the fact that citizenship not only includes a status or a (formal) identity in 
terms of something that you are or are not, have or do not have, such as social and cultural constructs and among other things, identity (Arnot \& Dillabough, 2000; Norman \& Kymlicka, 1994). The concept of citizenship also addresses individual and collective activity and action-taking; something that you do (Isin \& Nielsen, 2008; van Gunsteren, 1998). This doing involves the words and deeds of everyday living, which takes place inside or outside institutional settings as well as in civic life (Lawy \& Biesta, 2009; Lundahl \& Olson, 2013). In order to understand how citizen formation in adult education emerges we need, if the importance of these dimensions is accepted, to study a range of conditions, phenomena and processes that the adult students address in their description of citizenship (Olson, 2012; Dahlstedt \& Olson, 2014; Nicoll et al, 2013; Olson et al 2015).

Against this backdrop, we start from a perspective of citizenship that approaches it as something not already given, but rather a continuing process of making (Cruikshank, 1999; White \& Hunt, 2000; Procacci, 2004). In this light, citizenship does not have a natural, given essence, but instead it is about the continual creation of activity and action-taking upon the concept and practice of citizenship as such (Dahlstedt, 2009; Nicoll et al., 2013).

Taking on citizenship is something that changes over time, and always in intimate relationship with the societal and historical, social and material conditions at hand - it links the citizen training role of adult education with its given historical and social context. It stresses the need for seeing the citizen training role of education in the society that surrounds it and, inversely, seeing in what way this society is shaping this role. From this point of departure, the theoretically underpinned analysis of adult student citizen formation contributes on the one hand to the existing literature on the relationship between citizenship and adult education, and on the other hand, it contributes to existing research on the role and purpose of adult education in society in general.

Re(dis)covering will - reactive nihilism, adult education and late capitalism

With the point of departure in such a notion of citizenship, we particularly draw on the Deleuzian political theorist Bülent Diken (2009) and his notion of 'reactive 
nihilism'. Diken belongs to those contemporary theorists working in a post-structural tradition historically charged by scholars such as Nietzsche and Spinoza, and more recently promoted, for example, by Foucault, Deleuze and Guattari.

We have chosen a post-structuralist theorisation as it can offer, we argue, vital perspectives on the relationship between citizenship and the field of adult education (cf. Usher 2010). More specifically, such an approach has an advantage, we claim, in that most current research in citizenship education sits within a positivist genre. This means that it is to a vast extent concerned with seeking new truths of or for citizenship education, in one way or another aiming to improve citizenship education or making it more effective. Such research might be productive, but at the same time limited through this aim, as it is not able to consider the actual effects of such truths, or consider reflexively its own involvement in the truth-making of citizenship education.

Put simply, a dominant research approach to the relationship between citizenship and (adult) education is one seeking the truth of citizenship education, while that adopted here seeks to understand the effects of truth claims regarding citizenship. In the following, we provide a brief introduction to a post-structural, nihilist approach to citizenship education, launching some of the main ontological and epistemological hallmarks in the field of education, following with a post-structural, nihilist approach, and setting Diken's concept of 'reactive nihilism' on stage for the article's line of argument.

\section{Nihilism}

Turning to the concept of nihilism, it is an ontological and epistemological gesture arising at a particular time and place in modern history, as noted already by Heidegger:

Nihilism is a historical moment, and not just any view or doctrine advocated by someone or another. Nihilism moves history after the manner of a fundamental ongoing event that is scarcely recognized in the destining of the Western peoples. Hence, nihilism is also not simply one historical phenomenon among others/../Nihilism, thought in its essence, is, rather, the fundamental movement of the history of the West. (Heidegger, 1977, p. 62) 
Well acquainted with the historicity of nihilism, Diken (2009) sets out from the classical philosophical post-structural nihilist position marked out by situating the beginning of nihilism in modernity, in the 'death of God', i.e. in the origin of origins. This scenery links nihilism with religiosity, which is the relationship that entails the very nerve for the arousal of nihilism. This religious nihilism divides itself in two; 'radical' and 'passive’ (or reactive) nihilism.

The first one, escapism or radical nihilism, insists on transcendence by taking the negation of this world to its logical extreme - the total destruction or denial of the actual world. The second one gives up its resistance or denial of the actual world, and instead neglects or refutes the 'poisoning' properties of passion and values in this world (Nietzsche, 1996, p. 22; see also Zizek, 2001; Badiou, 2007). In terms of willingness, the first form of nihilism is marked out by the annihilation of the will, while the other denotes the willingness to nothing (that is poisoning, i.e. causes hurt, pain and conflict). The form of nihilism that Diken calls 'perfect nihilism', is a combination of nihilism and anti-nihilism. It is a combination of these seemingly disjunctive gestures in that it inhabits a constructive element of consolidating immanent values in this world. And the way in which this is to be done is by hammering down all icons that nihilism itself has set up in its own religiosity. That is, not even the values or principles set up by nihilism itself, in its destructive or at least neglecting impulse, can be saved if nihilism as a historically situated and settled ontological gesture is not to break down on its own command (see Diken, 2009).

As for the aim of this article, we focus on the second form of nihilism, reactive nihilism. In this form, there is no objective meaning or intrinsic value (to find) in the world. Related to our aim in this article, there is consequently nothing to learn, teach or in any sense acquire, in or through education (cf. Reitter \& Wellmon, 2016). This means that there are no higher or external, transcendent values, entities, factual knowledge or grand narratives for students enrolled in education to embody or embrace because they are higher or better per se. Such entities as values or inherent meaning are themselves seen as illusory, which is quite well outlined in the work of both Nietzsche (1969) and Spinoza (1993) - the two scholars that have most clearly come to represent the classical notion of nihilism. 
What is referred to by Deleuze and Guattari (1983) as 'the virtual' in relation to this ontological position, is a constantly ongoing flow of feelings, dispositions, positions and direction-taking in the world and in society (Colebrook, 2002). However, this real world of flows is not what people are faced with. Instead, they face administrated and directed aspirations and tamed emotions in certain ways when they meet up with them. Taking on the aim of the article, we may say that these offers, i.e. the potential promise of the virtual for any being to face not (yet) administrated feelings and dispositions in the world, are not possible to administrate in any conceivable way, either for the single student or for the educational site itself.

This is so, as the potentiality of the virtual to offer not (yet) administrated feelings and dispositions does not come into being, as they have been arranged and channelized in special ways over time, in different societies, as a consequence of the cemented conditions made available for this arrangement, in each time and place. Furthermore, the channelling of offers of feelings, intensities and aspirations that is administrated and directed in a particular educational site is actually located at the very heart of the task of (adult) education, being one of the main reproductive institutions of modern societies.

Relating this perspective to our concern in this article, adult education comes into being as a societal institution administrating and directing certain ways (at the expense of others) of handling these offers for its students in their processes of citizen formation. What meets up with these ongoing processes in adult education are thus rather hegemonic and solidified repertoires of ways of administrating and directing the ongoing offers of citizen dispositions, positions and action-taking that this educational site produces and distributes. Consequently, the citizen formation made available in this educational site can be seen as an effect of what is being offered and distributed for the students in this formation of citizens.

With Diken (2009), these effects - played out in different ways of channelling and responding to (here) the educational offers of feelings, aspirations, dispositions and action-taking that the adult students act upon - denote some forms of nihilism more than others. They do so in that these effects can be traced back to different historically 
enabled forms of acting toward what-is (i.e. the actual world, with its offers of feelings, dispositions, positions and action-taking). These forms of enactment to whatis are not only played out in individual registers, but also in collective registers in society at large. Diken's point is that different effects, i.e. ways of (re)acting toward what-is, are in fact what characterises a society.

Taking on the aim of this article, our tracing of the adult students' citizen formation processes leads us to claim that these processes denote a reactive nihilistic enactment. Furthermore, these enactments can be traced historically to denote a societal situation of today, which we - with Diken - may identify as one of late capitalism.

\section{Late capitalism and reactive nihilism}

According to Diken, today's society is marked out by ways of (re)acting that denote a society of late capitalism. The late capitalist society can be described in terms of a machine fuelled, among other things, by will-making as the main driving force. The capitalist machine is nurtured by commercialised market forces. This machinery is played out in constantly ongoing loops of demand and supply of goods and services. One central drive in the never-ending drive for enhancement, or expansion, of capitalist life in society is desire, or will-making. What is at stake here is that this desire, or will-making, needs to be constantly fed, aroused, nurtured and extinguished (i.e. satisfied) in order for its residents to consume anew, i.e. to keep up the neverending loops of demand and supply of goods and services, if this society is to keep itself actualised (cf. Deleuze \& Guattari, 1983).

One key component of this capitalist machinery of ever-lasting loops of arousal and extinction is desire, or will formation. This will formation is intimately linked with a (sense of) lack of satisfaction: if there is no sense of lack of something that is sensed as a need, an aspiration or longing for something - which calls for satisfaction of this lack - there is no investment or provocation that nurtures the citizens' (re)actiontaking toward consumption of the goods and services offered in this society. Furthermore, if there is no desire, no mobilisation of will to consume these offers, fed by the needs and longing, the capitalist society eventually dies. And when this lack of need, and furthermore, of desire, becomes collectively repeated and widespread among its residents, the very nerve of the capitalist machinery dies. At the same time, 
its institutionalised ways of administrating and directing feelings, aspirations and action-taking routes - adult education among them - also die.

The stance-taking of the students' enactment on the proposals made possible through the societal and educational administration of feelings and aspirations could, in the words of Diken (2009), be characterised as reactive rather than active - or, to put it in the words of Nietzsche (1968), 'passive' or 'powerless'. And this reactive stancetaking is what denotes the reactive nihilistic position.

Turning to the relationship between citizenship and adult education, this particular societal situation is fuelled by certain kinds of affect and stimuli, which conditions the very production of directions for citizenship subjectivity made possible in this society and its institutions. It is this production, together with the question about what this production tells about the role of adult education in the late capitalist society of today, which are our main interest in this article. Bringing this theoretical explicatory grid into the citizen formation made possible in the site of adult education as part of the late capitalist society, we argue that adult education could be understood as a societal site where certain processes of citizen formation are made possible for the students while other are not. In these processes, the students' will formation, the formation of the students as willing subjects, stands out as a vibrant part.

\section{Adult education as a space for will formation}

In the following, a few adult students' descriptions of citizenship and about themselves as citizens are presented, in order to undertake a theoretically underpinned tracing some crucial elements in the processes of citizen formation as they take place in Swedish adult education. The material consists of interviews with adult students enrolled in the two major educational sites in Swedish adult education: municipal adult education [MAE], and non-formal adult education, folk high schools [FHS]. The interviews were conducted in 2013 and 2014 in a MAE school in two larger cities, and in a FHS school in a medium large city in Sweden.

Students in these schools were interviewed about their participation in adult education, their notions of what it means to be a citizen in relation to their trajectories 
of the future and lives here-and-now, and what citizenship activities emerge within and beyond the practices of adult education. A brief contextual grid of adult education in the Swedish context is here provided. MAE and FHS are often positioned in policy and in practice as places for second chances for i.e. (often young) adults who have failed schooling, or adults who have migrated to Sweden. According to the supranational policy agenda (cf. UNESCO, 1997; WHO, 2005), the aim of the Swedish national adult education assignment of citizen formation is to both provide knowledge necessary for the individual in order to manage herself in the labour market, and to take an active part in society politically, economically and socially ([Swedish] Ministry of Education, 2013a, 2013b). Adult education is thus, through policy-making, shaped as something positive, a place to 'prepare' adults for a life as citizens, which is seen as beneficial for both individuals and society (cf. Fejes, 2006).What stand out in our theoretical tracing of their descriptions are two things. Firstly, that the citizen formation taking place appears as a matter of re(dis)covery, of recovery and discovery of will, as a means for the students to become successful and happy in life and in society at large. Secondly, that this re(dis)covery of will emanates in an undecorated adaptation to the existent late capitalist society, which traces the effect of their citizen formation to that of the reactive nihilist's.

When asked about ways of being and becoming a citizen, of how citizenship is enacted, performed or played out in their own lives as students, the adult students repeatedly stress a need for change of direction in life. This stress is repetitively directed toward themselves, more precisely inwards, toward their own will and willingness. This direction-taking comes to the fore in various ways of wanting, such as wanting-to-feel-awareness or motivation for studying, in adult education as well as in further education, in wanting to find-out-what-I-want, in wanting-to-find-a-feeling of being on one's way in life.

Linnea's words quite elegantly illustrate this intricate stance-taking toward the students themselves and their (educational) situation:

One must have the will, I do not think that just because I want anything on a basic level, it will happen. Then I would only be comfortable with the everyday life that I already have. But I want something, a little more, a little extra. If I want it a little extra I will work for it, and not just have it like a dream. (Linnea, MAE)

The need for a strong willingness points at a general urge for the mobilisation of will, which is necessary to create in order to making a life plan or a job plan. These words 
point toward a particular kind of citizen formation involving a discovery of one's own will. Put differently, in order to realise one's dreams about the future in society one has to be in charge of one's own process of will formation, i.e. one has to become a willing subject.

These processes of re(dis)covering will stand out as an individually, and to some extent educationally fuelled devotion to moulding, rearranging and reinvesting in one's own repertoires of will. And among the adult students, the 'object of will' in question is often driven by an envisioning of an imagined future. This envisioning of the future seems to mark out a process of citizenship formation that is conditioned, in the sense that their will-creation is somehow deficient and in need of being moulded and adjusted to the requirements, expectations and structures of society. The adult students must, so to speak, invest in themselves, their wilful ambitions and activities as citizens. Out of this envisioning, the correction of ill-fitting wills stands out as necessary for the adult students in order for them to become successful and happy citizens:

When one succeeds in satisfying all these... needs that are part of the pyramid [referring to Maslow's stair of needs] in one way or the other, in order to finally in the end be able to realize oneself. That is part of democracy. (Simon, FHS)

In this process of will formation, adult education becomes a catalyst, a site where the (self-)mobilisation of will is both enabled, sanctioned and part of the envisioning force itself, as regards the citizen formation made possible in this educational site. Filip points toward this educational enablement when describing the reason for him being enrolled in adult education as, "because I do not have a feeling of what I want' (Filip, MAE).

Taken together, the adult students' mobilisation of will is marked out by a double orientation toward both self-construction (giving birth to and feeding new wills), and self-destruction (killing existing wills in order to create another will-direction), which seems to be part of the motive for being enrolled in adult education in the first place.

With Diken (2009, p. 7), we may say that the "willful disappearance (i.e. selfdestruction) seems to become a technology; a dispositive of the self' fuelling the 
possible action-taking as a citizen on the site of adult education, in life and in society. ${ }^{2}$ Far from claiming any exhaustive or fully-fledged picture of the processes of citizenship formation among adult students, we argue that these illustrating examples render visible the central mechanisms in these processes. These illustrations allow the formulation of a tentative argument that the very enterprise of adult students' citizen formation is a matter of constantly ongoing will formation, in order for the adult students to adjust their selves to the (cemented flows of affect and stimuli involved in the) notion of success and happiness driven by the capitalist apparatus, of which adult education is part.

This constantly ongoing adjustment to society as-it-is can, according to Diken, be traced back to the spirit of the late capitalist society itself. This society is fuelled by the ongoing and never-ending flow-drive of desire to will something (rather than nothing). The sensing of desire to will provides the student with a sense of (being on her way to) fulfilment and satisfaction of self in the present. And being enrolled in adult education is a safe-way-to-get-there. Taking on Diken's line of argument, we might say that the feeling of self-fulfilment is intimately related to the wanting-ofthings that are available and desirable according to the current distribution of desire in society.

According to Diken (2009), this cementation of the direction of desire is exactly what characterises the market-oriented, late capitalist society, where satisfaction of needs and pleasures are the nerve of this societal apparatus. This nerve - the enactments of constant mobilisation of will - is played out and actively promoted by the students enrolled in adult education.

Out of this theorization, we may say that what is enabled for the students in the citizen formation made possible in the site of adult education in the late capitalist society is to have control over self, in order to adjust strengths and weaknesses in relation to the alleged and sensed lack (of self-fulfilment), and in order to nurture ones' own body of desire so that it does not break down on its own over- or under-consumptive desirefor-success-and-happiness command. This process, then, points back to the role and 
function of adult education itself, and predicates feasibly important notions of this role.

\section{Reactive nihilist citizenship through adult education - conclusion and} outlook

What does the adult students' will formation more specifically stress, in relation to our theoretical point of departure? And what stands out as the main role for adult education as an institution assigned to see to the citizen training of its students?

Departing from the notion that adult education not only has an assignment to provide for the students' citizen training, but also serves as a space for the reproduction of the late capitalist society, we argue that one central mechanism (among others) in the processes of citizen formation made possible for the students is that of the reactive nihilist.

The role of adult education, then, appears to be that of offering the students opportunities to mobilise their own wills as a crucial mechanism in their citizen formation. Here, adult education could be described as a waiting room, a site where students are to work upon their bodies and souls in order to mobilise their willingness in ways that effectuate citizenship trajectories as part of their citizen existence in the present late capitalist society. Zafirah (MAE) tellingly addresses this particular role of adult education when saying that adult education 'is not part of the way, it is just a place for ... getting to the way that you are willing to reach'. The logic of this exercise is that of self-adjustment to what-is, i.e. to an already existing late capitalist society, where self-fulfilment through success (in working life as well as in private life) and happiness (through fulfilment of needs) stands out as key.

Like Diken (2009), we argue that the students' will-making denotes a citizen formation marked out by a specific stance-taking toward society, and by adult students' social conditions of possibility to make a difference in this society. It directs away from a fuelling of willingness to change society, in favour of a fuelling of an instant and ongoing need to revise and mobilise (the will to) change oneself and one’s 
self, in order to adapt to an already existing society (Olson \& Dahlstedt, 2014). What is unsubscribed in this understanding of society, education and citizenship, is the tacit circumstance, or even circumscription, that another existence, another society - other ways of becoming a citizen - is not possible (Tesfahuney \& Dahlstedt 2008). Accordingly, the future does not seem to exist, as the order of things guiding the future follows the parameters of an already existing late capitalism. Out of this scenery, different futures with their related mechanisms are possible, as are other existences and ways of becoming a citizen.

\section{References}

Arnot, M. \& Dillabough J-A. (eds) (2000). Challenging Democracy. International Perspectives on Gender, Education and Citizenship. London: Routledge Falmer.

Badiou, A. (2007). The Century. Cambridge/Malden: Polity Press.

Biesta, G. J.J. (2011). Learning Democracy in School and Society. Education, Lifelong learning, and the Politics of Citizenship. Rotterdam: Sense Publishers.

Colebrook, C. (2002). Understanding Deleuze. Crows nest: Allen and Unwin.

Cruikshank, B. (1999). The Will to Empower: Democratic Citizens and Other Subjects. New York: Cornell University Press.

Dahlstedt, M. (2009). Aktiveringens politik: Demokrati och medborgarskap för ett nytt millennium. Malmö: Liber.

Dahlstedt, M. Rundqvist, M. \& Vesterberg, V. (2013). Medborgarskap: rättigheter, skyldigheter och medborgarideal i förändring. In Dahlstedt, M. \& Neergaard, A. (Eds) Migrationens och etnicitetens epok: Kritiska perspektiv i etnicitets- och migrationsstudier, Stockholm: Liber.

Deleuze G. \& F. Guattari (1987). A Thousand Plateaus: Capitalism and Schizophrenia. London/New York: Continuum.

Diken, B. (2009). Nihilism. London and New York: Routledge.

Fejes, A. (2006). The planetspeak discourse of lifelong learning in Sweden: What is an educable adult? Journal of Education policy, 21(6), 697-716. 
Fejes, A. (2010) Discourses on Employability: Constituting the Responsible Citizen. Studies in Continuing Education, 32(2), 89-102.

Filander, K. (2012). Discursive turns from 'Bildung' to managerialism: Memory-work of the Finnish adult education generations. European Journal for Research on the Education and Learning of adults, 3(2), 135-153.

Hedtke, R \& T. Zimenkova (eds) (2012) Education for Civic and Political Participation: A Critical Approach. London: Routledge.

Heidegger, M. (1977). The Question Concerning Technology, and Other Essays. Transl. W. Lowitt. New York/London: Garland Publishers.

Isin, E.F. \& Nielsen, G.M. (2008). Introduction. In E.F. Isin \& G.M. Nielsen (eds) Acts of Citizenship. New York: Zed Books.

Isin, E.F. \& Wood, P.K. (1999). Citizenship and Identity. London: Sage.

Lawy, R. \& Biesta, G. J.J. (2006) Citizenship-as-practice: the educational implications fo an inclusive and relational understanding of citizenship. British Journal of Educational Studies, 54(1), 34-50.

Lawy, R., Biesta, G J.J. \& Kelly, N. (2009). Understanding young people's citizenship learning in everyday life: the role of contexts, relationships and dispositions. Education, Citizenship and Social Justice, 4(1), 5-24.

Lundahl, L. \& Olson, M. (2013). Democracy lessons in market-oriented schools: The case of Swedish upper secondary education. Education, Citizenship and Social Justice, 8(2), 201-213.

Marshall, T.H. (1950). Citizenship and Social Class. Cambridge: Cambridge University Press.

McDonough, K. \& W. Feinberg (2005). Citizenship and Education in Liberal-Democratic Societies: Teaching for Cosmopolitan Values and Collective Identities. Oxford: Oxford University press.

Milana, M. (2012). Political globalization and the shift from adult education to lifelong learning. European Journal for Research on the Education and Learning of adults, 3(2), 103-117.

Ministry of Education (2013a). SOU 2013:76, Svenska för invandrare: valfrihet, flexibilitet och individanpassning. Stockholm: Utbildningsdepartementet. [Swedish for immigrants: freedom of choice, flexibility and personalization] 
Ministry of Education (2013b). SOU 2013:20, Kommunal vuxenutbildning på grundläggande nivå: En översyn för ökad individanpassning och effektivitet. Stockholm: Utbildningsdepartementet. [Basic level municipal adult education: A review aimed at increased personalization and efficiency]

Nietzsche, F. (1968). The Will to Power. W. Kaufmann and R.J Hollingdale. (transl). New York: Vintage books.

Nietzsche, F. (1969). Twilight of Idols. London: Penguin.

Nietzsche, F. (1996). Human, All Too Human. Schact, R. (ed), Hollingdale, R.J. transl. Cambridge: Cambridge University Press.

Nicoll, K., Fejes, A., Olson, M., Dahlstedt, M., \& Biesta, G. J.J. (2013). Opening discourses of citizenship education: A theorization with Foucault. Journal of Education Policy, 28(6), 828-846.

Nicoll, K. \& Fejes, A. (2011). Lifelong learning: A pacification of 'know how'. Studies in Philosophy and Education, 30(4), 403-417.

Niklasson, L. (2007). Medborgaren som pedagogiskt projekt. Stockholm: Stockholm University Press.

Norman, W. \& Kymlicka, W. (1994). Return of the Citizen: A Survey of Recent Work on Citizenship Theory. Ethics, 104(2), 352-381.

Öhrn, E., Lundahl, L. \& Beach, D. (eds) (2011). Young people's influence and democratic education: Ethnographic studies in upper secondary schools. London: Tufnell Press.

Olson, M. (2009). Democratic Citizenship - A Conditioned Apprenticeship. A Call for Destabilisation of Democracy in Education. Journal of Social Science Education, 8(4), 75- 80.

Olson, M. (2012). What Counts as Young People's Civic Engagement in Times of Accountability? On the Importance of Maintaining Openness about Young People's Civic Engagement in Education. In M. Olson (guest ed.): Citizenship education under liberal democracy: To be or not to be a (properly educated) citizen - comments on the ICCS 2009 study. Utbildning \& Demokrati, 21(1), 29-55.

Olson, M. \& Dahlstedt, M. (2014). Citizenship formation for a new millennium - a prognosis of our time. Journal of Critical Education Policy Studies 12(2), 200-224.

Olson, M., Fejes, A., Dahlstedt, M., \& Nicoll, K. (2015). Citizenship discourses: Production and curriculum. British Journal of Sociology of Education, 36(7), 1036-1053.

Procacci, G. (2004). New challenges to citizenship. In P. Baert, S. M. Koniordos, G. Procacci \& C. Ruzza (eds). Conflict, Citizenship and Civil society. London/New York: Routledge (pp. 13-21).

Reitter, P. \& Wellmon, C. (eds) (2016). Anti-Education/by Friedrich Nietzsche. New York: The New York Review of book 
Rahm, L. \& Fejes, A. (2015). Ubiquitous computing, digital failures and citizenship learning in Swedish popular education. Citizenship Teaching \& Learning, 10(2), 127-142.

Sandberg, F., Fejes, A., Dahlstedt, M., \& Olson, M. (2015). Adult education as a heterotopia of deviation: a dwelling for the abnormal citizen. Adult Education Quarterly, 66(2), 103-119.

Siivonen, P. \& Brunila, K. (2014). The making of an entrepreneurial subjectivity in adult education, $\begin{array}{llll}\text { Studies in } \quad \text { Continuing } & \text { Education, }\end{array}$

Spinoza, B. (1993). Ethics. London: Everyman.

Tesfahuney, M. \& Dahlstedt, M. (eds) (2008). Den bästa av världar? Stockholm: Tankekraft.

UNESCO (1997). International Standard Classification of Education (ISCED). Electronic resource:

www.uis.unesco.org/Library/Documents/isced97-en.pdf. (Retrieved 160425)

Usher, R. (2010). Riding the lines of flight. European Journal for the Research on the Education and Learning of Adults, 1(1-2), 67-78.

van Gunsteren, H. (1998). Theory of Citizenship: Organizing Plurality in Contemporary Democracies. Oxford/Colorado: Westview Press.

White M. \& Hunt A. (2000). Citizenship: care of the self, character and personality. Citizenship Studies, 4(2) 93-116.

WHO (2005). World Health Organization. Promoting mental health. Concepts, emerging evidence, practice. A report of the World Health Organization. Geneva. Electronic resource:

http://www.who.int/mental_health/evidence/MH_Promotion_Book.pdf (Retrieved 150920).

Zizek, S. (2001). On belief. London: Routledge.

\footnotetext{
1 The article draws on data within a larger project on citizenship education within and beyond adult education, see Nicoll et al. (2013), Olson et al. (2015), Rahm \& Fejes (2015); Sandberg et al. (2016). ${ }^{2}$ To draw on a parallel way of describing this process, Slavoj Zizek (2001) suggests that what is made possible through this process is ‘the (political) gesture of sublimation’ (p. 127).
} 